\title{
Polycyclic Aromatic Hydrocarbons in Soil Around Coal-Fired Power Plants in Shandong, China
}

\author{
Qiqi Cheng ${ }^{1}$, Wei Ge ${ }^{2}$, Chao Chai ${ }^{1 *}$, Juan Wu ${ }^{1}$, Dong Ma ${ }^{1}$, Lusheng Zeng ${ }^{1}$, \\ Xiangwei Zhu' ${ }^{1}$, Qinghua Chen ${ }^{1}$, Jingsuo $\mathbf{L i}^{3}$
}

\begin{abstract}
${ }^{1}$ Qingdao Engineering Research Center for Rural Environment, Qingdao Agricultural University, Qingdao, China ${ }^{2}$ College of Life Sciences, Qingdao Agricultural University, Qingdao, China

${ }^{3}$ College of Management, Qingdao Agricultural University, Qingdao, China
\end{abstract}

Received: 26 November 2017

Accepted: 2 January 2018

\begin{abstract}
This study comprehensively investigated the concentrations, distribution patterns, sources, and health risks of 16 polycyclic aromatic hydrocarbons (PAHs) found in soils around two thermal power plants in Shandong, China. The total concentrations of the 16 total PAHs $\left(\Sigma_{16} \mathrm{PAH}\right)$ in the Longguang (LG) and Xinyuan (XY) thermal power plants were 1,031.78-2,744.06 and 1,383.8-2,924.8 $\mu \mathrm{g} / \mathrm{kg}$, respectively, with mean values of $1,925.2$ and $2,303.1 \mu \mathrm{g} / \mathrm{kg}$, respectively. Seven carcinogenic PAHs accounted for $45.5 \%$ and $55.7 \%$ of $\Sigma_{16}$ PAHs in soils around LG and XY thermal power plants, respectively. A similar composition pattern of PAHs was observed in soils around the two power plants. The contributions of four-ring PAHs, namely, fluoranthene (FLA), pyrene (PYR), benz[a]anthracene (BaA), and chrysene (CHR), were high; thus, the four-ring PAHs dominated in soils around the two power plants. With the increase of distance, most individual PAH concentrations decreased, and $\sum_{16}$ PAHs concentrations decreased significantly from $200 \mathrm{~m}$ to $500 \mathrm{~m}$. However, the contributions of two- to three-ring PAHs increased with distance, whereas the contributions of four-ring PAHs decreased. Four PAH sources in soils around the two thermal power plants were identified by positive matrix factorization. Coal combustion was the main source of soil PAHs. Health-risk assessment based on toxic equivalency factors of benzo[a]pyrene indicated no risk of PAH contamination in soils around LG power plant and a low risk in those around XY power plant. This study highlights the distribution and sources of PAHs in soil around thermal power plants.
\end{abstract}

Keywords: PAHs, coal-fired power plant, soil, positive matrix factorization, risk assessment

\section{Introduction}

Polycyclic aromatic hydrocarbons (PAHs) are a group of organic compounds including two or more aromatic

*e-mail: chaichao1999@126.com rings [1], and human health can be threatened by their teratogenicity, carcinogenicity, and mutagenicity [2]. They can be eliminated via biological degradation [3] and photodegradation [4], and their content in the environment can generally be maintained at a low level. However, in recent years, this balance has been destroyed due to anthropogenic activities, which are the main sources of 
PAHs [5]. Consequently, PAHs are now ubiquitous in the environment, and their content in the environment has increased [6]. PAHs are most probably derived from diffuse sources, such as dry and wet deposition from the atmosphere [2], and they tend to accumulate in soil.

With the development of industrialization, coal has become one of the most abundant and important sources of global energy. In 2015 global coal production was 8.00 billion tons, and total coal production in China was 3.65 billion tons [7]. In the same year, coal consumption in China was 3.97 billion tons, which accounted for about half of global coal consumption [8]. The share of coal in energy consumption in China has reached $64 \%$, which is far higher than the global average level of $30 \%$ [9]. Coal combustion is an important source of PAHs, particularly some carcinogenic species. Most studies on pollution from coal-fired power plants have focused on fly ash around large industrial coal-fired plants [10]. These studies show that phenanthrene is the dominant $\mathrm{PAH}$ and that more than $80 \%$ of the PAHs found in ash samples around coal-fired plants exist as three- and four-ring PAHs [11]. In addition, the total PAH content of fly ash is higher than that of bottom ash [12]. The high concentrations of PAHs detected in leaves of shrubs near coal-fired power plants could pinpoint conspicuous air contamination [13]. A number of reports have shown that coal tar is an important source of urban PAH and that high $\mathrm{PAH}$ concentrations in soil and water have been detected in the vicinity of coal or coal gangue dumps [14-15]. Obvious differences have also been observed in the PAH content of soil in the northern and southern regions of China. The content of PAHs in soil in the southern region of China is generally lower than that in the northern region, probably because of coal firing in the latter [16]. However, research on the composition, variation with distance, sources, and health risks of PAHs in soil affected by coal-firing is scarce.

Shandong Province $\left(34.61-37.91^{\circ} \mathrm{N}\right.$ and 115.08 $122.41^{\circ} \mathrm{E}$ ) is one of the largest industrial producers in northern China. It is dominated by petroleum, chemical, electronic, fertilizer, tire, and rubber industries. It has a temperate climate with an average annual temperature of $11-14^{\circ} \mathrm{C}$ and annual precipitation $550-950 \mathrm{~mm}$. In China, Shandong has the greatest number or the highest installed capacity of coal-fired power plants. The Longguang (LG) thermal power plant and Xinyuan (XY) thermal power plant are located in Weifang and Zaozhuang, Shandong, respectively. The LG thermal power plant utilizes $12 \mathrm{MW}$ generator sets, whereas the XY thermal power plant utilizes $30 \mathrm{MW}$ generator sets. Both power plants have been in operation for more than10 years, and they share the same geographical position and climate conditions. Given these similarities, we chose the two power plants for this study. The study measured the concentrations of PAHs in soils around the LG and XY coal-fired power plants. Then we aimed to (1) analyze the variation of PAHs with distance, (2) fingerprint the sources of PAHs, and (3) evaluate the human health risks of PAHs in soils around coal-fired power plants. The results will broaden the understanding of characteristics of PAHs in contaminated soils near thermal power plants.

\section{Materials and Methods}

\section{Soil Sampling}

Thirteen surface soil samples $(0-20 \mathrm{~cm})$ from around the LG and XY power plants were collected in July 2015 (Fig. 1). Four samples were collected from

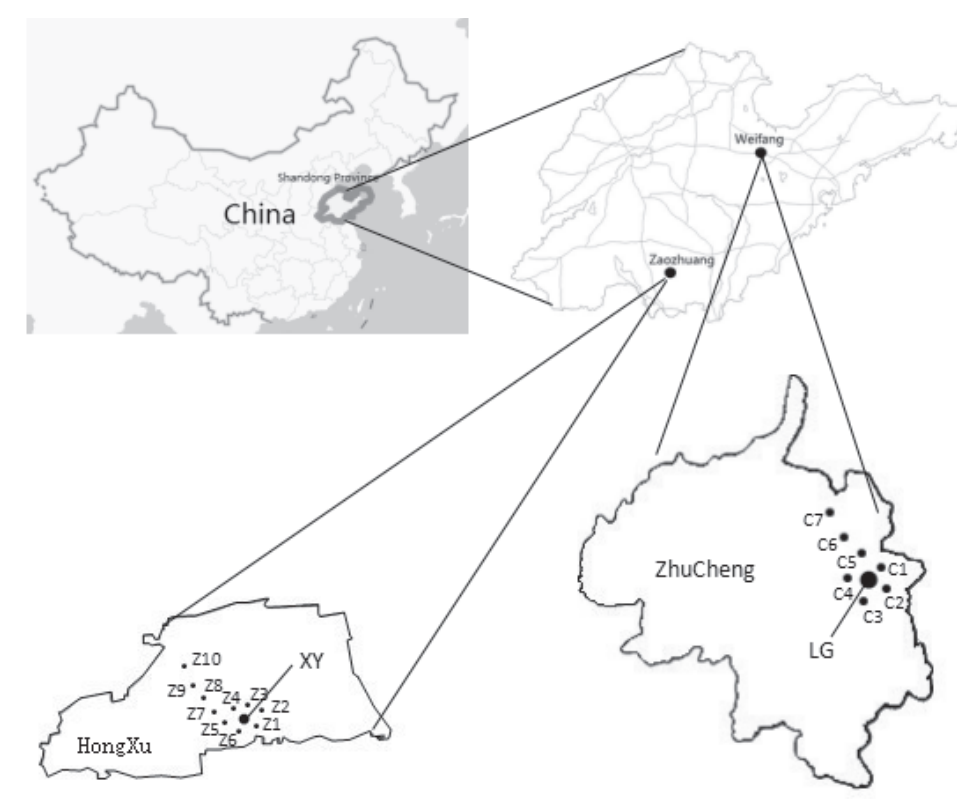

Fig. 1. Schematic map showing soil sampling sites around Longguang and Xinyuan power plants in Shandong. 
the area close to the LG power plant, six samples were collected from the area close to the XY power plant, and three samples were collected at distances of 200, 500, and $1000 \mathrm{~m}$ from the LG and XY power plants, respectively. All the samples were freeze-dried, homogenized, sieved into 20-mesh-sized particles, and then kept in a refrigerator at $-4^{\circ} \mathrm{C}$.

\section{Sample Extraction and Cleanup}

Exactly $2 \mathrm{~g}$ of soil samples and $10 \mathrm{~mL}$ dichloromethane (DCM) were put into a $30 \mathrm{~mL}$ centrifuge tube, which was sonicated for $1 \mathrm{~h}$. The mixture was centrifuged at 4,000 r/min for $10 \mathrm{~min}$, and the extract was collected. The same extraction process was repeated by adding $10 \mathrm{~mL}$ DCM. The two extracted solutions were combined and concentrated to approximately $1 \mathrm{~mL}$ through rotary evaporation. The silica gel was used to clean up the concentrated solution. The glass chromatography column $(20 \mathrm{~cm} \times 10 \mathrm{~mm}$ i.d. $)$ was packed from the bottom with $4 \mathrm{~g}$ activated silica gel (200-300 mesh) and $4 \mathrm{~g}$ anhydrous sodium sulfate. Elution was performed with $20 \mathrm{~mL} \mathrm{DCM}$ and n-hexane $(\mathrm{v}: \mathrm{v}=1: 1)$. The eluent was further concentrated nearly to dryness and solvent-exchanged to $2.0 \mathrm{~mL}$ methanol for analysis.

\section{High-Performance Liquid Chromatography Analysis}

PAH concentration was measured through highperformance liquid chromatography equipped with an ultraviolet and fluorescent detector (HPLC-UV-FLD, Shimadzu). Then, 16 PAHs were separated with an Inertsil ODS-P column $(250 \times 4.6 \mathrm{~mm}, 3.5 \mu \mathrm{m}$ particle size, $1,000 \mathrm{~nm}$ pore size) with the mobile phase of methanol-water (80:20, by volume) through gradient elution with a flow rate of $1.0 \mathrm{~mL} / \mathrm{min}$. Detection was carried out with the FLD wavelength switching program at excitation wavelengths of 265, 260, 290, and $250 \mathrm{~nm}$, and emission wavelengths of 420, 430, and $500 \mathrm{~nm}$. UV detection with a double wavelength pattern was performed at wavelength channel 1 of $254 \mathrm{~nm}$ and wavelength channel 2 of 220, 280, and $210 \mathrm{~nm}$. The column temperature was set to $40^{\circ} \mathrm{C}$, and the injection volume was $20 \mu \mathrm{L}$.

A composite standard solution of 16 PAHs, including naphthalene (NAP), acenaphthene (ACE), acenaphthylene (ACY), fluorene (FLU), phenanthrene (PHE), anthracene (ANT), fluoranthene (FLA), pyrene (PYR), benz[a] anthracene (BaA), chrysene (CHR), benzo[b]fluoranthene $(\mathrm{BbF})$, benzo[k]fluoranthene $(\mathrm{BkF})$, benzo[a]pyrene (BaP), dibenzo[a,h]anthracene (DBA), indeno[1,2,3cd]pyrene (IPY), and benzo[ghi]perylene (BPE) was purchased from AccuStandard Company (USA). All solvents were HPLC grade.

\section{Quality Assurance and Quality Control}

The method blank was applied and showed no detectable amounts of PAHs. The sample duplicate was analyzed, and the variation in PAH concentrations was less than $9 \%$. The recoveries of the procedure of the 16 PAHs were controlled in the range of $60.2-119.3 \%$, and the relative standard deviation was $0.6-14.8 \%$.

The external standard calibration method was implemented, and determined instrument stability and confirmed the calibration curve by analyzing the standard mixture for every 10 samples. The limits of detection were in the range of $0.07 \mu \mathrm{g} / \mathrm{kg}$ to $2 \mu \mathrm{g} / \mathrm{kg}$.

\section{Source Identification Methods}

In this study, the emission sources of PAHs in the soil samples were distinguished by diagnostic ratios and the positive matrix factorization (PMF) model. Diagnostic ratios have been commonly applied to distinguish the sources of PAHs [17]. However, the ratios cannot provide accurate information on the contributions of PAH sources [18]. Therefore, the PMF model, which was developed in 1994, was used in this study. The concrete calculation method for the parameters of the PMF model was based on the work of Reff et al. (2007) [19-20]. The current work used the U.S. EPA PMF 5.0 model [21]. The measured $\mathrm{PAH}$ concentration and the estimated uncertainty $(u)$ of the concentration are required for the PMF 5.0 model. In the concentration file, the concentration of PAHs below the method detection limits (MDL) was substituted by half the detection limit. The uncertainty of the concentration was calculated by applying MDL to each PAH and the measurement uncertainties (MU) defined as $10 \%$ of the measured concentration values. If the concentration $\leq \mathrm{MDL}$, the uncertainty $u$ is calculated as

$$
u=\frac{5}{6} \times \mathrm{MDL}
$$

...and when the concentration $>$ MDL, $u$ is calculated as:

$u=\sqrt{(\mathrm{MU} \times \text { concentration })^{2}+(\mathrm{MDL})^{2}}$

\section{PAH Risk Assessment}

Benzo[a]pyrene equivalent concentrations $\left(\mathrm{BaP}_{\text {eq }}\right)$ could be estimated by using benzo[a]pyrene toxic equivalency factors (TEFs). The carcinogenicity of the other PAHs relative to $\mathrm{BaP}$ was quantified to estimate $\mathrm{BaP}_{\text {eq }}$ [22]. $\mathrm{BaP}_{\text {eq }}$ was calculated according to Eq. 1 [23]:

$$
\mathrm{BaP}_{\mathrm{eq}}=\mathrm{C}_{\mathrm{i}} \times \mathrm{TEF}_{\mathrm{i}}
$$

...where $\mathrm{C}_{\mathrm{i}}$ is the concentration of ith $\mathrm{PAH}(\mu \mathrm{g} / \mathrm{kg})$ and $\mathrm{TEF}_{\mathrm{i}}$ is the toxic equivalency factor of ith PAH. 


\section{Results and Discussion}

\section{PAH Concentrations and Composition}

The total concentrations of the 16 PAHs $\left(\sum_{16} \mathrm{PAHs}\right)$ in soils around the LG power plant varied from $1,031.8 \mu \mathrm{g} / \mathrm{kg}$ to $2,744.1 \mu \mathrm{g} / \mathrm{kg}$, with a mean of $1,936.2 \mu \mathrm{g} / \mathrm{kg}$ (Table 1). The concentrations of seven carcinogenic PAHs ( $\Sigma$ CPAHs; including BaA, CHR, $\mathrm{BbF}, \mathrm{BkF}, \mathrm{BaP}, \mathrm{IPY}$, and $\mathrm{DBA}$ ) were in the range of $541.2 \mu \mathrm{g} / \mathrm{kg}$ to $1,355.7 \mu \mathrm{g} / \mathrm{kg}$, accounting for $45.5 \%$ of $\Sigma_{16}$ PAHs. In terms of the concentrations of the PAHs of different rings, the concentrations of the four-ring PAHs were high with a mean of $862.3 \mu \mathrm{g} / \mathrm{kg}$, followed by the five-ring PAHs. The concentrations of the six- and two- to three-ring PAHs were relatively low.

$\sum_{16} \mathrm{PAHs}$ in soils around the $\mathrm{XY}$ power plant varied from $2,252.4 \mu \mathrm{g} / \mathrm{kg}$ to $3,924.8 \mu \mathrm{g} / \mathrm{kg}$, with a mean of $2,594.4 \mu \mathrm{g} / \mathrm{kg}$. $\Sigma$ CPAHs were in the range of $1,181.4 \mu \mathrm{g} / \mathrm{kg}$ to $1,966.4 \mu \mathrm{g} / \mathrm{kg}$, with a mean concentration of $1,445.0 \mu \mathrm{g} / \mathrm{kg}$, which accounted for
$55.7 \%$ of $\Sigma_{16}$ PAHs. The concentration of the four-ring PAH was relatively high with a mean of $1,138.5 \mu \mathrm{g} / \mathrm{kg}$, followed by the concentrations of the five-ring and twoto three-ring PAHs. The concentration of the six-ring PAHs was relatively low.

Maliszewska-Kordybach established a standard classification method for PAH-contaminated soil according to the data of soil from several European countries and combined it with the risk of human exposure [24]. According to this standard, all the soil samples around the two power plants were heavily contaminated $(>1,000 \mu \mathrm{g} / \mathrm{kg})$.

$\sum_{16}$ PAHs in soils around the point sources are presented in Table 2. The PAH concentrations in this study were lower than those around other coal-fired power plants, such as those in India $(2538.24 \mu \mathrm{g} / \mathrm{kg})$ [13], South Africa $(9,730-61,240 \mu \mathrm{g} / \mathrm{kg}$ ) [2] and Huainan $(2,830-5,320 \mu \mathrm{g} / \mathrm{kg})$ [25]. The PAH concentrations in the coking areas in Shanxi Province in China $(171.67-3,176.79 \mu \mathrm{g} / \mathrm{kg})$ and a coking plant in France $(1,355.78 \mu \mathrm{g} / \mathrm{kg})$ were comparable to those in this

Table 1. Concentrations of PAHs in soils around the LG and XY power plants ( $\mu \mathrm{g} / \mathrm{kg})$.

\begin{tabular}{|c|c|c|c|c|c|c|c|c|c|c|}
\hline \multirow{2}{*}{ Compounds } & \multicolumn{5}{|c|}{ LG power plant } & \multicolumn{5}{|c|}{ XY power plant } \\
\hline & Min & Max & Mean & Median & SD & Min & Max & Mean & Median & SD \\
\hline NAP & 21.5 & 66.8 & 38.8 & 33.5 & 20.1 & 16.6 & 48.2 & 32.1 & 32.1 & 11.2 \\
\hline $\mathrm{ACY}$ & 60.4 & 78.2 & 69.8 & 70.3 & 8.0 & 60.1 & 80.4 & 72.8 & 73.9 & 6.8 \\
\hline $\mathrm{ACE}$ & 18.0 & 50.5 & 31.1 & 28.0 & 14.3 & 19.5 & 45.8 & 28.7 & 26.7 & 9.8 \\
\hline FLU & 3.5 & 9.8 & 6.7 & 6.8 & 2.6 & 7.9 & 143.0 & 59.1 & 51.6 & 49.8 \\
\hline PHE & 2.0 & 29.4 & 14.6 & 13.5 & 14.2 & 28.9 & 63.0 & 45.2 & 42.7 & 13.6 \\
\hline ANT & 35.7 & 192.4 & 121.9 & 129.7 & 80.0 & 167.2 & 491.1 & 272.8 & 245.9 & 125.6 \\
\hline FLA & 108.2 & 373.8 & 190.2 & 139.3 & 123.3 & 148.3 & 304.9 & 217.4 & 213.2 & 57.1 \\
\hline PYR & 211.7 & 358.6 & 302.2 & 319.4 & 67.3 & 69.4 & 308.7 & 180.6 & 186.5 & 95.5 \\
\hline $\mathrm{BaA}$ & 124.3 & 508.3 & 269.3 & 222.3 & 182.4 & 338.1 & 538.7 & 436.9 & 412.7 & 78.1 \\
\hline CHR & 50.1 & 246.7 & 100.6 & 52.7 & 97.4 & 210.8 & 518.2 & 303.6 & 284.7 & 112.6 \\
\hline $\mathrm{BbF}$ & 24.9 & 74.8 & 44.7 & 39.5 & 22.8 & 45.4 & 66.7 & 55.7 & 54.1 & 8.5 \\
\hline $\mathrm{BkF}$ & 202.5 & 420.5 & 315.8 & 320.1 & 100.6 & 40.2 & 85.4 & 57.2 & 50.5 & 16.8 \\
\hline $\mathrm{BaP}$ & 3.0 & 40.4 & 21.6 & 21.5 & 21.4 & 6.7 & 80.5 & 32.3 & 26.3 & 27.7 \\
\hline DBA & 105.8 & 128.7 & 121.8 & 126.4 & 10.9 & 239.4 & 586.2 & 460.7 & 477.7 & 116.5 \\
\hline BPE & 16.7 & 495.8 & 279.9 & 303.6 & 197.5 & 49.3 & 493.3 & 240.7 & 208.6 & 190.0 \\
\hline IPY & 5.2 & 9.0 & 7.1 & 7.1 & 1.8 & 45.7 & 123.0 & 98.6 & 107.3 & 28.0 \\
\hline $2 \sim 3$ rings & 154.0 & 423.6 & 282.9 & 277.0 & 117.3 & 352.8 & 851.5 & 510.6 & 463.9 & 185.6 \\
\hline 4 rings & 497.8 & 1419.7 & 862.3 & 765.8 & 400.6 & 945.4 & 1670.6 & 1138.5 & 1072.1 & 269.0 \\
\hline 5 rings & 355.0 & 641.5 & 503.9 & 509.6 & 136.3 & 380.8 & 816.9 & 605.9 & 605.8 & 141.3 \\
\hline 6 rings & 25.0 & 501.0 & 287.1 & 311.1 & 196.3 & 159.0 & 585.8 & 339.3 & 289.3 & 188.1 \\
\hline$\sum \mathrm{CPAHs}$ & 541.2 & 1355.7 & 880.9 & 813.4 & 341.7 & 1181.4 & 1966.4 & 1445.0 & 1381.4 & 268.5 \\
\hline$\sum_{16} \mathrm{PAHs}$ & 1031.8 & 2744.1 & 1936.2 & 1984.5 & 712.1 & 2252.4 & 3924.8 & 2594.4 & 2335.5 & 655.4 \\
\hline
\end{tabular}


Table 2. Total concentrations of $16 \mathrm{PAHs}(\mu \mathrm{g} / \mathrm{kg})$ in soils around point sources.

\begin{tabular}{|c|c|c|c|c|}
\hline Region/area & Sampling site types & Range & Mean & Reference \\
\hline Anhui Province, China & Coal mines & $130 \sim 3540$ & 840 & Wang et al.(2010a) \\
\hline Xinzhou, China & Coal production area & n.d. $\sim 782$ & 202 & Zhao et al.(2014) \\
\hline Shanxi, China & Coking areas & $171.67 \sim 3176.79$ & 982.18 & Cui et al. (2015) \\
\hline Shanxi, China & Coke production base & $247 \sim 1410$ & 691 & Duan et al. (2015) \\
\hline France & \multicolumn{2}{|c|}{ Coking plant } & 1335.78 & Biache et al. (2008) \\
\hline Indian & Coal-fired power plant & $951.79 \sim 4362.35$ & 2538.24 & Sharma et al. (2009) \\
\hline South Africa & Coal-fired power plants & \multicolumn{2}{|c|}{$9730 \sim 61240$} & Okedeyi et al. (2013) \\
\hline Huainan, China & Coal-fired power plants & $2830 \sim 5320$ & & Wang et al. (2013a) \\
\hline China & Thermal desorption plant & $3180 \sim 3532$ & 3338.2 & Liu et al. (2015) \\
\hline Milan, Italy & \multicolumn{2}{|c|}{ Manufacturing gas plant } & 1669300 & Saponaro et al. (2002) \\
\hline Gdańsk, Poland & Municipal solid waste & $892 \sim 3514$ & 1974 & Melnyk et al. (2015) \\
\hline Guangdong, China & E-waste recycling site & $127 \sim 10600$ & 1230 & Wang et al. (2012) \\
\hline Taizhou, China & E-waste recycling town & $262.6 \sim 3420.2$ & 1095.8 & Tang et al. (2010) \\
\hline Longtang, China & E-waste recycling site & $25 \sim 4300$ & 514.4 & Huang et al. (2014) \\
\hline Taizhou, China & E-waste recycling sites & $330 \sim 790$ & 566.67 & Shen et al. (2009) \\
\hline Abraka, Nigeria & Fuel stations & $0.82 \sim 62.98$ & 14.48 & Emoyan et al.(2011) \\
\hline Arizona, USA & Urban highway & $67 \sim 10117$ & 523 & Marusenko et al. (2011) \\
\hline Zhejiang, China & Municipal waste incinerator & $2222.53 \sim 6883.91$ & 3859.06 & Shen et al. (2010) \\
\hline Yangtze River Delta region, China & Industrial areas & 471.30 & & Wang et al. (2017) \\
\hline Zhucheng, China & Coal-fired power plant & $1031.8 \sim 3744.8$ & 1925.2 & In this study \\
\hline Zaozhuang, China & Coal-fired power plant & $1383.8 \sim 3924.8$ & 2303.1 & In this study \\
\hline
\end{tabular}

study [26-27], but they were higher than those in soils from the coal production area in Anhui Province $(840 \mu \mathrm{g} / \mathrm{kg}) \quad$ [28], Xinzhou (n.d.-782 $\mu \mathrm{g} / \mathrm{kg}$ ) [18] and Shanxi (247-1,410 $\mu \mathrm{g} / \mathrm{kg})$ [29] in China. Furthermore, the PAH concentrations in this study were higher than those in most e-waste recycling sites in Guangdong $(1,230 \mu \mathrm{g} / \mathrm{kg})$ and Taizhou (262.6-3,420.2 $\mu \mathrm{g} / \mathrm{kg}$; $330-790 \mu \mathrm{g} / \mathrm{kg}$ ) in China [30-32].

The PAH concentrations in this study and other areas around the power plants were lower than those of a thermal desorption plant $(3,338.2 \mu \mathrm{g} / \mathrm{kg})$, municipal waste incinerator in Zhejiang (222.53-6,883.91 $\mu \mathrm{g} / \mathrm{kg})$, and manufacturing gas plant $(1,669,300 \mu \mathrm{g} / \mathrm{kg})$ [33$35]$. By contrast, they were higher than those of fuel stations (0.82-62.98 $\mu \mathrm{g} / \mathrm{kg})$, urban highway $(523 \mu \mathrm{g} / \mathrm{kg})$, industrial areas $(471.3 \mu \mathrm{g} / \mathrm{kg})$, and municipal solid waste site $(1,974 \mu \mathrm{g} / \mathrm{kg})$ [36-39]. Therefore, the PAH concentrations in soils around the coal-fired power plants in this study were in the middle range.

In soils around the LG power plant, BkF, PYR, BPE, and $\mathrm{BaA}$ were the major $\mathrm{PAH}$ compounds, accounting for $16.3 \%, 15.6 \%, 14.5 \%$, and $13.9 \%$ of the total PAHs, respectively (Fig. 2). In soils around the XY power plant, DBA, BaA, CHR, and ANT were the major
PAH compounds, accounting for $17.8 \%, 16.8 \%, 11.7 \%$, and $10.5 \%$, respectively. A similar composition pattern of PAHs was observed in soils around the two power plants. The contributions of the four-ring PAHs, including FLA, PYR, BaA, and CHR, were high, resulting in the

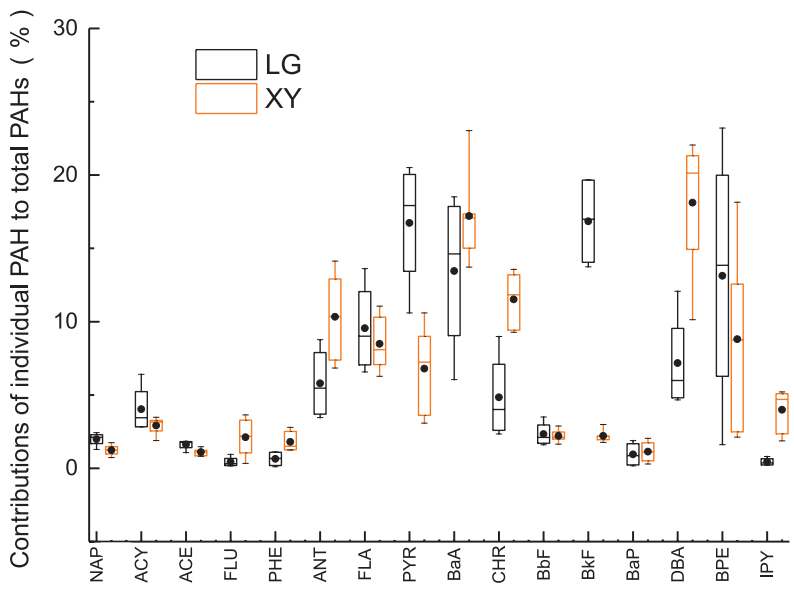

Fig. 2. Contributions (\%) of individual PAH compounds (lines on top, bottom, and middle denote max., min., and median values, respectively; dot denotes the mean value). 
four-ring PAHs being predominant with a concentration of $44.6 \%$ in the LG power plants and $44.0 \%$ in the XY power plants. Although the contributions of $\mathrm{BkF}$ and DBA in the two power plants differed, the contributions of the five-ring PAHs were in the range of $20-30 \%$, followed by those of the four-ring PAHs. Even with the contributions of BPE (one of six-ring PAHs) being high in the two power plants, the contributions of the six-ring PAHs were relatively low, accounting for $13.0 \%$ of that in the LG power plant and $12.8 \%$ of that in the XY power plant. By comparison, the contributions of the two- to three-ring PAHs in the two power plants were also less than $20 \%$.

$\mathrm{BaA}$ showed high concentrations in soil samples from around the two thermal power plants, whereas $\mathrm{BaP}$ and PHE showed a small proportion. DBA in soil samples around the $\mathrm{XY}$ thermal power plant and $\mathrm{BkF}$ in soil samples around the LG thermal power plant showed large proportions, but they showed a smaller proportion in soil samples around another thermal power plant. Previous studies found that the most abundant PAHs around a power plant in South Africa were CHR, BkF, and IPY [3]. The finding of the current study is similar to this result.

PHE, FLA, BbF, NAP, PYR, and CHR were dominant in soil samples from a coke production base [28], whereas ANT, ACE, DBA, PYR, and CHR were dominant in soil samples from around a fuel station [36]. Some of the major compounds identified in the coke production base and fuel station were consistent with the results obtained for the two power plants $[29,36]$. In soils around an e-waste recycling area, the most abundant PAHs were NAP, PHE, and FLU [30]. In all samples around a thermal desorption plant in China, the most abundant PAHs were FLU and ANT [33]. In all the soil samples around a manufacturing gas plant site, the most abundant PAHs were FLA, PYR, $\mathrm{BaP}$, and IPY [35]. Given the availability of various sources, the composition of PAHs in soils from different sampling site types is disparate.

\section{Variation of PAHs with Distance}

With increasing distance, most PAH compound concentrations decreased, and $\sum_{16} \mathrm{PAH}$ concentrations decreased significantly from $200 \mathrm{~m}$ to $500 \mathrm{~m}$ (Fig. 3). The mean $\sum_{16} \mathrm{PAH}$ concentrations in soils from a distance of $1,000 \mathrm{~m}$ from the $\mathrm{LG}$ and $\mathrm{XY}$ power plants were $1,593.45 \mu \mathrm{g} / \mathrm{kg}$ and $1,475.87 \mu \mathrm{g} / \mathrm{kg}$, respectively. The contributions of PAHs with different rings presented a difference with distance. The contributions of two- to three-rings PAHs increased with distance from 14.6\% to $27.3 \%$ in soils near LG and from $19.7 \%$ to more than $35 \%$ in soils near XY. However, the contributions of the four-ring PAHs decreased from $45 \%$ to $30-35 \%$. The contributions of the five-ring PAHs in soils near LG increased with distance from $26.0 \%$ to $33.1 \%$, but near the XY power plant, the contributions decreased from $23.4 \%$ to $16.9 \%$ (Fig. 4). The contributions of the six-ring PAHs decreased from $14.8 \%$ to $10.2 \%$ and from $13.1 \%$ to $11.2 \%$

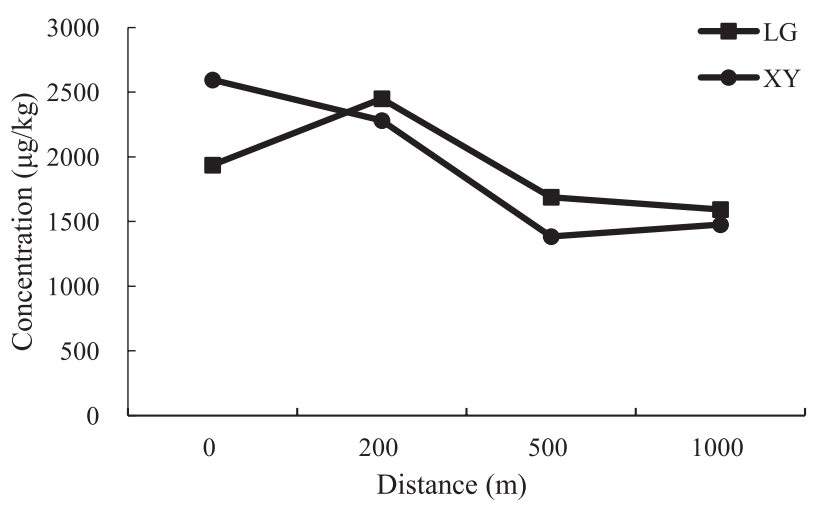

Fig. 3. Variation of 16 PAH concentrations with distance in soils from the LG a) and XY b) power plants.

in soils near the LG and XY power plants, respectively. Despite the changes in contributions, the four- and fivering PAHs still accounted for a large percentage at a distance of $1,000 \mathrm{~m}$ from the two power plants.

Low molecular weight PAHs (LMW PAHs, $\leq$ three rings) exhibit high vapor pressure, exist mainly in the gaseous phase, and can be transported for a long distance [40]. Thus, the percentage of two- to three-rings PAHs increases with distance [41]. Moreover, LMW PAHs migrate more easily than high molecular weight PAHs (HMW PAHs, $\geq$ four rings) [42]. The samples sites around the $\mathrm{XY}$ power plant were situated at altitudes of $67,66,65$, and $58 \mathrm{~m}$ at a distances of $0,200,500$, and $1,000 \mathrm{~m}$, respectively. The decrease in altitude with distance may help LMW PAHs migrate in the soil [43]. On the contrary, HMW PAHs cannot easily be migrated and may even accumulate in soils found adjacent to the power plants. A garbage transfer station was situated at a distance of $700 \mathrm{~m}$ away from the LG power plant, and a transportation center was located at a distance of about $600 \mathrm{~m}$ from the XY power plant. Previous studies found that these point sources may release a great deal of LMW PAHs, such as ANT and FLU, resulting in the high contributions of LMW PAHs [37, 39].

\section{Source Identifications and Contributions}

The ratios of $\mathrm{ANT} /(\mathrm{ANT}+\mathrm{PHE})$ and $\mathrm{BaA} /(\mathrm{BaA}+\mathrm{CHR})$ have been proposed as an indicator of petrogenic or pyrogenic sources [44]. The ratio of ANT/(ANT+PHE) $<0.10$ is identified as petrogenic emissions, whereas the value $>0.10$ is characteristic of combustion (pyrogenic emissions) [45]. The ratio of $\mathrm{BaA} /(\mathrm{BaA}+\mathrm{CHR})<0.20$ is identified as petrogenic emissions, whereas a value $>0.35$ is characteristic of combustion (pyrogenic emissions) [46]. The ratios of $\mathrm{ANT} /(\mathrm{ANT}+\mathrm{PHE})$ and $\mathrm{BaA} /(\mathrm{BaA}+\mathrm{CHR})$ in soils around the LG and XY power plants both indicated that the PAHs derived from combustion (Fig. 5). Coal firing is the primary energy source for thermal power plants [47]. It is consistent with the fact that the main PAH contribution in soils around the thermal power plants in 

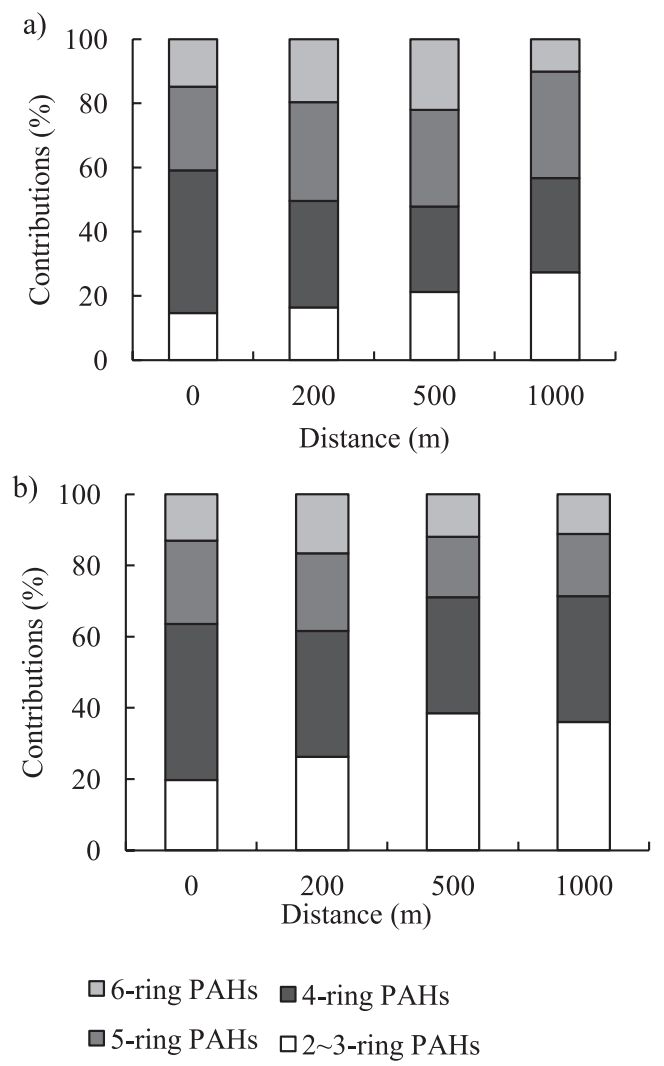

Fig. 4. Variation of contributions of PAHs (\%) with distance in soils around the LG a) and XY b) power plants.

this work was due to the abundance of coal combustion and diesel combustion. Similar results were found in other areas in China. The ratios of ANT/(ANT+PHE) and FLA/(FLA+PYR) indicated that the main sources of soil PAHs in Beijing and Tianjin were biomass burning; in Dalian, the main source was petroleum combustion [48-49]. However, several points on Fig. 5 are relatively decentralized, which indicates that except for coal combustion, some other sources also were conducive to PAH contamination in soils from the study area [18].

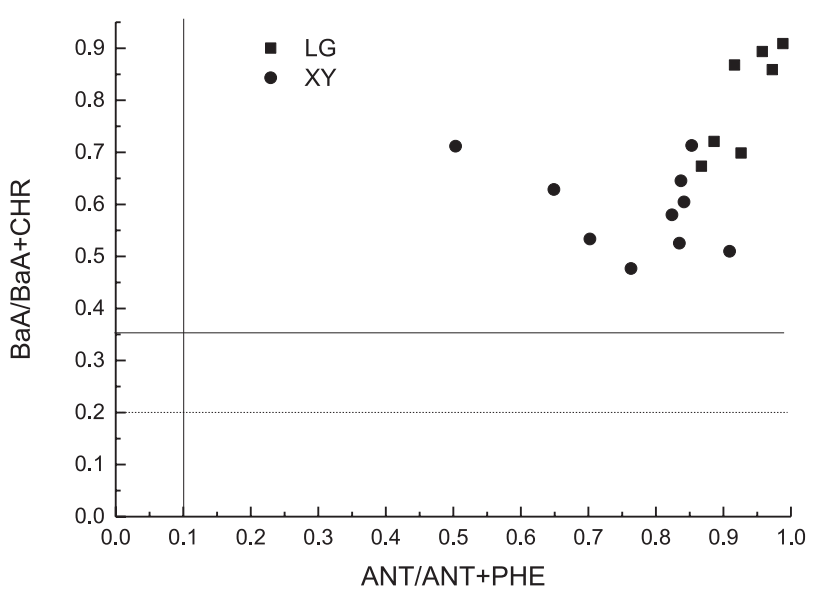

Fig. 5. Molecular diagnostic ratios of PAHs in soil in the LG and $\mathrm{XY}$ power plants.
The PMF model provided the source profiles and the contribution of each factor [50], are presented in Fig. 6 to distinguish the sources of PAHs in soils around the LG and XY power plants.

In soils around of the LG power plant, factor 1 characterized by NAP, ACE, BaP, ANT, and FLA contributed $23.2 \%$ to total PAHs. Incomplete combustion could generate Nap, and Nap could serve as an indicator of petroleum sources [51]. BaP, ANT, and FLA indicate the combustion of coal [52]. Therefore, Factor 1 is labeled as an incomplete coal combustion source. Factor 2 , accounting $33.3 \%$ of the total PAHs, was mainly associated with IPY, FLU, CHR, and DBA. These compounds indicate fuel combustion [51], and diesel emissions are characterized by CHR and DBA [5354]. Therefore, Factor 2 could be denoted as a traffic source factor. Factor 3, accounting for $21.1 \%$ of total PAHs, has high loadings of PHE, BaP, ANT, and FLU. Coal combustion could be traced by these compounds [55]. PHE is typically derived from coal or coal combustion [54]. ANT and FLU are predominant in coal combustion signals [56]. Therefore, Factor 3 is assigned as a coal source factor. Factor 4, accounting for $22.4 \%$ of total PAHs, has high loadings of BPE, CHR, PYR, and BkF. BPE is related to gasoline emissions [52]. CHR, BkF, and PYR were identified as diesel emissions [57]. Therefore, Factor 4 indicates a gasoline and diesel emissions source. Therefore, the primary source of PAHs in soil samples around the LG power plant is coal combustion.

In soil samples around the XY power plant, Factor 1, which contributed $23.0 \%$ of the total PAHs, was weighted predominately by DBA, FLU, BPE, and CHR. This characteristic is due to vehicle emissions generating high concentrations of CHR, BaP, and HMW PAHs, such as $\mathrm{BPE}$ and $\mathrm{BkF}$ [55]. Factor 1 could be denoted as a vehicle emissions factor. Factor 2, explaining $25.7 \%$ of the total PAHs, had high loadings of BaP, FLU, ACE, NAP, and IPY. LMW PAHs are generally delivered from petroleum and its products, as well as purified oil products [58-59]. Fossil fuel combustion and coking would produce HMW PAHs [46]. Factor 2 was both highly loaded with LMW and HMW PAHs, which is consistent with coal burning as the primary source of the mixed source pollution. Factor 3 contributed $16.6 \%$ of the total PAHs and has high loading of PYR, BkF, BaP, ANT, and BbF. Fossil fuel combustion could produce PYR [60]. BaP and $\mathrm{BbF}$ were the main contributors for this factor, and both of them are makers of diesel combustion [52, 61]. Factor 3 was chosen to represent a pyrogenic source. Factor 4 , accounting $34.7 \%$ of the total PAHs, was highly loaded with BkF, BaA, ANT, IPY, PHE, and DBA. BkF, $\mathrm{BaA}$, and ANT were related to the coal combustion source [54]. Therefore, Factor 4 was assigned as a coal source factor.

The main source of PAHs in soil samples around the two power plants is coal combustion, which produces heat to make the water evaporate and the steam turbine rotate to produce electrical power in coal-fired power 
plants [62]. This process could explain why the coal combustion source is the main source in the LG and XY power plants.

The LG power plant is located in the center of town next to a fair. Thus, the traffic in this area is heavy. A transportation center is situated in the northeastern portion of the XY power plant. The frequent transportation activities could explain the traffic source, accounting for the large loading. The boilers of thermal power plants generally use diesel for ignition, and power plants are equipped with a diesel oil tank, which may result in the spilling of diesel [63].
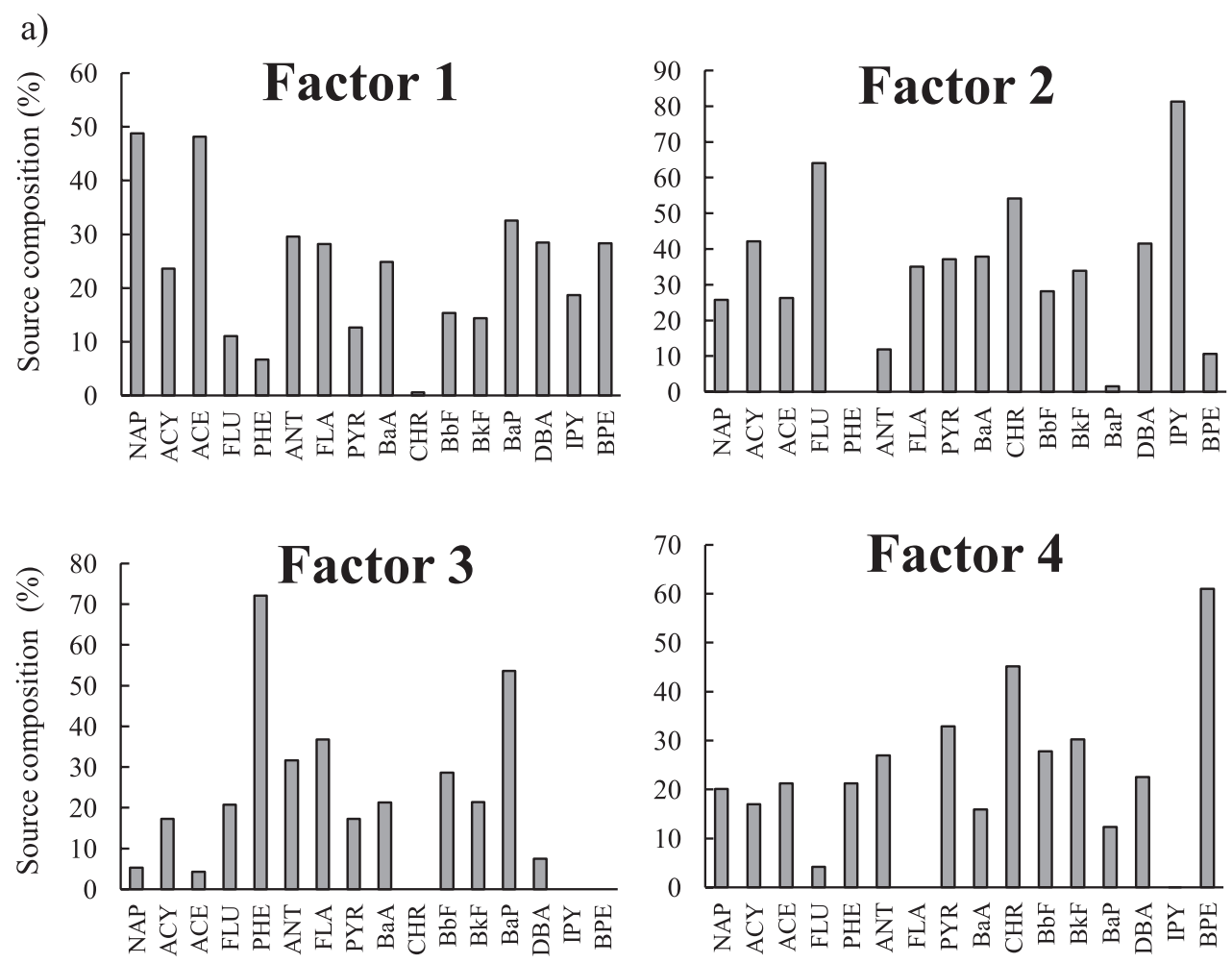

b)
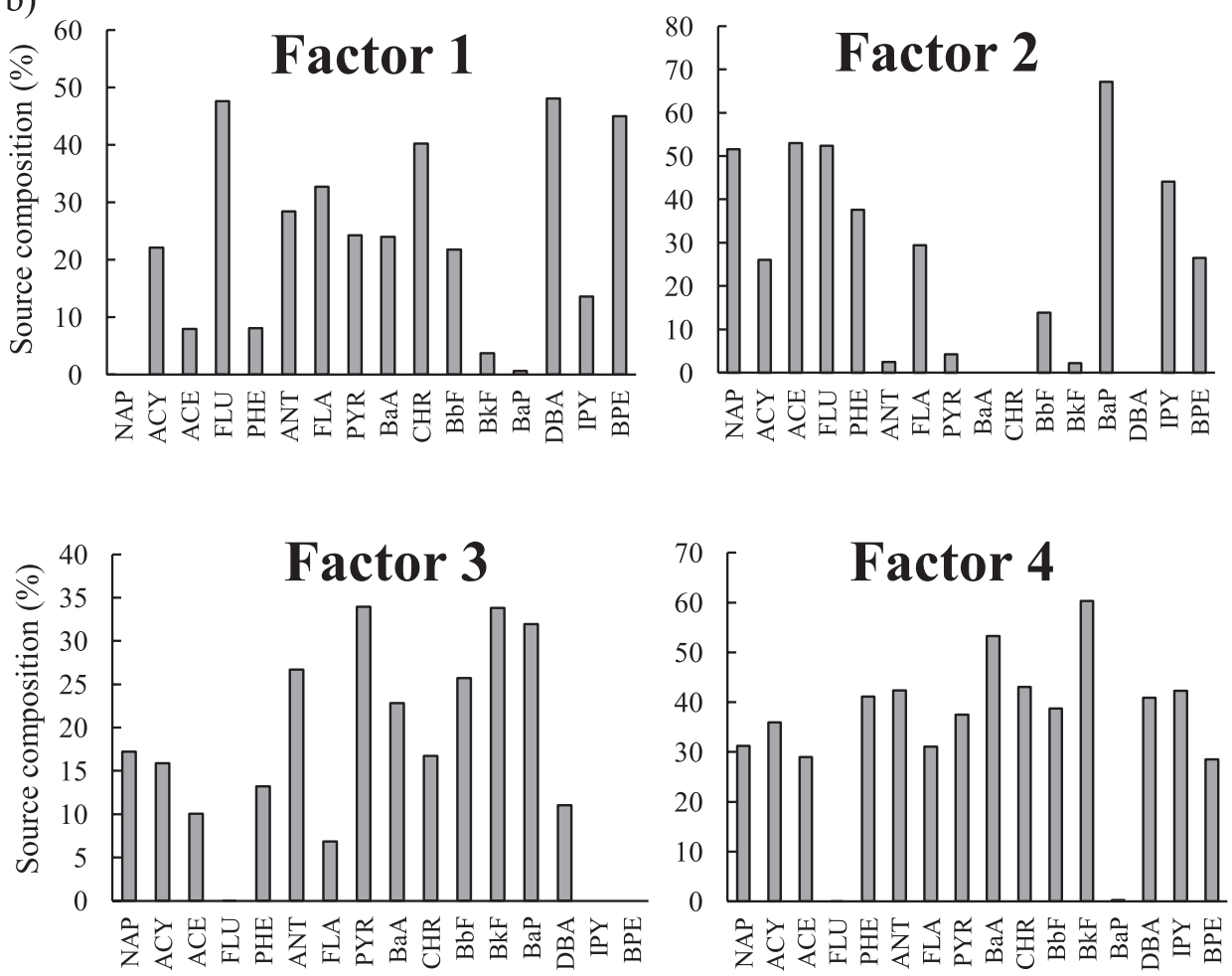

Fig. 6. Source profiles of PAHs in soil around the LG (a) and XY (b) power plants obtained with the PMF model. 


\section{Health-Risk Assessment}

In soil samples around the LG power plant, $\mathrm{BaP}_{\text {eq }}$ concentrations of the $16 \mathrm{PAHs}$ ranged from $164.6 \mu \mathrm{g} / \mathrm{kg}$ to $268.3 \mu \mathrm{g} / \mathrm{kg}$, with a mean value of $211.9 \mu \mathrm{g} / \mathrm{kg}$ (Table 3). In soil samples around the XY thermal power plant, $\mathrm{BaP}_{\text {eq }}$ concentrations of the $16 \mathrm{PAHs}$ ranged from $347.5 \mu \mathrm{g} / \mathrm{kg}$ to $756.2 \mu \mathrm{g} / \mathrm{kg}$, with a mean value of $563.9 \mu \mathrm{g} / \mathrm{kg}$. The $\mathrm{BaP}_{\mathrm{eq}}$ concentrations in this study are higher than those in the urban and suburban areas of Nanjing (445 and $215 \mu \mathrm{g} / \mathrm{kg}$ ) [9], the industrial district in Jinan $(262 \mu \mathrm{g} / \mathrm{kg})$, urban areas of Shanghai $(428 \mu \mathrm{g} / \mathrm{kg}$ ), and the farmland soil of Shouguang $(23.1 \mu \mathrm{g} / \mathrm{kg})[64-66]$. By contrast, the $\mathrm{BaP}_{\text {eq }}$ concentrations in the study areas are lower than those in the steel mill area in Fujian Province $(852 \mu \mathrm{g} / \mathrm{kg})$ [67].

The Canadian Soil Quality Guidelines for the Protection of Environmental and Human Health indicates that the safe value of $\mathrm{BaP}_{\text {eq }}$ in soil is $600 \mu \mathrm{g} / \mathrm{kg}$ [68]. The results showed that all concentrations of the samples from around the LG power plant were below the safe value, and $16.7 \%$ of the samples around the XY power plant showed concentrations above the safe value. Therefore, no risk of PAHs was found in soils around the LG power plant, and a low risk of PAHs was observed in soils around the XY power plant. The generator sets of the XY thermal power plant $(30 \mathrm{MW})$ were bigger than those of the LG thermal power plant (12 MW). Therefore,

Table 3. Toxic equivalent concentration (BaPeq) $(\mu \mathrm{g} / \mathrm{kg})$ of PAHs in soils from study areas.

\begin{tabular}{|c|c|c|c|}
\hline \multirow{2}{*}{ PAHs } & \multirow{2}{*}{ TEFs } & \multicolumn{2}{|c|}{ BaP $_{\text {eq }}$} \\
\cline { 3 - 4 } & & LG & XY \\
\hline NAP & 0.001 & $0.04 \pm 0.02$ & $0.03 \pm 0.01$ \\
\hline ACY & 0.001 & $0.07 \pm 0.01$ & $0.07 \pm 0.01$ \\
\hline ACE & 0.001 & $0.03 \pm 0.01$ & $0.03 \pm 0.01$ \\
\hline FLU & 0.001 & $0.01 \pm 0.00$ & $0.06 \pm 0.05$ \\
\hline PHE & 0.001 & $0.01 \pm 0.01$ & $0.05 \pm 0.01$ \\
\hline ANT & 0.01 & $1.22 \pm 0.08$ & $2.73 \pm 1.26$ \\
\hline FLA & 0.001 & $0.19 \pm 0.12$ & $0.22 \pm 0.06$ \\
\hline PYR & 0.001 & $0.30 \pm 0.07$ & $0.18 \pm 0.10$ \\
\hline BaA & 0.1 & $26.93 \pm 18.24$ & $43.69 \pm 7.81$ \\
\hline CHR & 0.01 & $0.01 \pm 0.01$ & $0.30 \pm 0.11$ \\
\hline BbF & 0.1 & $4.47 \pm 2.28$ & $5.57 \pm 0.85$ \\
\hline BkF & 0.1 & $31.58 \pm 10.06$ & $5.72 \pm 1.68$ \\
\hline BaP & 1 & $21.63 \pm 21.42$ & $32.32 \pm 27.69$ \\
\hline DBA & 1 & $121.80 \pm 10.85$ & $460.70 \pm 116.48$ \\
\hline BPE & 0.01 & $2.80 \pm 1.98$ & $2.41 \pm 1.90$ \\
\hline IPY & 0.1 & $0.71 \pm 0.18$ & $9.86 \pm 2.80$ \\
\hline$\sum_{16}$ PAHs & & $211.9 \pm 43.3$ & $563.9 \pm 130.5$ \\
\hline & & & \\
\hline
\end{tabular}

a large coal-fired power plant would cause serious pollution of PAHs. Human health would be threatened by contaminated soil, and thus close attention should be paid to soil and human health.

\section{Conclusions}

The PAHs in the surface soil samples around the two thermal power plants were heavily contaminated. The four-ring PAHs dominated all samples around the two power plants. With a gradual increase in distance, most individual PAH concentrations in soil samples decreased, and the total PAH concentrations decreased significantly from $200 \mathrm{~m}$ to $500 \mathrm{~m}$. The contributions of the two- to three-ring PAHs increased with distance, whereas the contributions of the four-ring PAHs decreased. The ratios $\mathrm{ANT} /(\mathrm{ANT}+\mathrm{PHE})$ and $\mathrm{BaA} /(\mathrm{BaA}+\mathrm{CHR})$ showed that these PAHs were emitted from combustion. The sources of PAHs in the two thermal power plants, as obtained with the PMF model, were coal combustion, traffic, diesel emission, and mixed sources; coal combustion was the main source. Risk assessment showed no risk of PAHs in soils around the LG power plant, but a low risk of PAHs in soils around the XY power plant.

\section{Acknowledgements}

This study was supported by the Special Fund for Agroscientific Research in the Public Interest (201503107) and Shandong Provincial Natural Science Foundation (ZR2017MC068).

\section{Conflict of Interest}

The authors declare no conflict of interest.

\section{References}

1. JUHASZ A.L., NAIDU R. Bioremediation of high molecular weight polycyclic aromatic hydrocarbons: a review of the microbial degradation of benzo[a]pyrene. International Biodeterioration \& Biodegradation, 45 (1-2), $57,2000$.

2. OKEDEYI O.O., NINDI M.M., DUBE S., AWOFOLU O.R. Distribution and potential sources of polycyclic aromatic hydrocarbons in soils around coal-fired power plants in South Africa. Environmental Monitoring \& Assessment, 185 (3), 2073, 2013.

3. ERIKSSON M., DALHAMMAR G., BORGKARLSON A.K. Biological degradation of selected hydrocarbons in an old PAH/creosote contaminated soil from a gas work site. Applied Microbiology \& Biotechnology, 53 (5), 619, 2000.

4. WILD E., DENT J., THOMAS G.O., JONES K.C. Real-time visualization and quantification of PAH photodegradation on and within plant leaves. Environmental Science \& Technology, 39 (1), 268, 2005. 
5. WANG H., SUN L.N., LIU Z., LUO Q., WANG X.X., WU H., SUN J.J. Pollution level and probabilistic cancer risk assessment of PAHs in surface water of Daliao River. Asia Journal of Ecotoxicology, 10 (4), 187, 2015 [In Chinese with English abstract].

6. ZHANG Y.X., TAO S., CAO J., JR C.R. Emission of polycyclic aromatic hydrocarbons in China by county. Environmental Science \& Technology, 41 (3), 683, 2007.

7. ZHANG J.H., JIANG X. The analysis and prospect of coal market in 2015 and the first quarter of 2016. China Steel, 5, 17, 2016 [In Chinese].

8. WANG X.Z. The world coal association technical committee meeting 2016.

9. WANG C.H., WU S.H., ZHOU S.L., WANG H., LI B.J., CHEN H., YU Y.N., SHI Y.X. Polycyclic aromatic hydrocarbons in soils from urban to rural areas in Nanjing: concentration, source, spatial distribution, and potential human health risk. Science of the Total Environments, 527528, 375, 2015.

10. LIANG J., FANG H.L., WU L.H., ZHANG T.L., WANG X.X. Characterization, distribution, and source analysis of metals and polycyclic aromatic hydrocarbons (PAHs) of atmospheric bulk deposition in Shanghai, China. Water, Air, \& Soil Pollution, 227 (7), 234, 2016.

11. LI H. Content and distribution of trace elements and polycyclic aromatic hydrocarbons in fly ash from a coalfired CHP plant. Aerosol \& Air Quality Research, 14 (4), 1179, 2014.

12. MASTO R.E., SARKAR E., GEORGE J., JYOTI K., DUTTA P., RAM L.C. PAHs and potentially toxic elements in the fly ash and bed ash of biomass fired power plants. Fuel Processing Technology, 132, 139, 2015.

13. SHARMA A.P., TRIPATHI B.D. Assessment of atmospheric PAHs profile through Calotropis gigantea R.Br. leaves in the vicinity of an Indian coal-fired power plant. Environmental Monitoring \& Assessment, 149 (1-4), 477, 2009.

14. WITTER A.E., NGUYEN M.H., BAIDAR S. Coal-tarbased sealcoated pavement: a major PAH source to urban stream sediments. Environmental Pollution, 185C (4), 59, 2004.

15. HUANG H.F., XING X.L., ZHANG Z.Z., QI S.H., YANG D., YUEN D.A., SANDY E.H., ZHOU A.G., LI X.Q. Polycyclic aromatic hydrocarbons (PAHs) in multimedia environment of Heshan coal district, Guangxi: distribution, source diagnosis and health risk assessment. Environmental Geochemistry and Health, 5, 1, 2016.

16. CAO Y.Z., LIU X.J., XIE Y.F., ZHANG D.D., LI F.S. Patterns of PAHs concentrations and components in surface soils of main areas in China. Acta Scientiae Circumstantiae, 32 (1), 197, 2012.

17. TOBISZEWSKI M., NAMIEŚNIK J. PAH diagnostic ratios for the identification of pollution emission sources. Environmental Pollution, 162 (1), 110, 2012.

18. ZHAO L., HOU H., SHANGGUAN Y.X., CHENG B., XU Y.F., ZHAO R.F., ZHANG Y.G., HUA X.Z., HUO X.L., ZHAO X.F. Occurrence, sources, and potential human health risks of polycyclic aromatic hydrocarbons in agricultural soils of the coal production area surrounding Xinzhou, China. Ecotoxicology \& Environmental Safety, 108, 120, 2014.

19. PAATERO P., TAPPER U. Positive matrix factorization: A non-negative factor model with optimal utilization of error estimates of data values. Environmetrics, 5 (5), 111, 1994.
20. ADAM R., SHELLY I.E., PRAKASH V.B. Receptor modeling of ambient particulate matter data using positive matrix factorization: review of existing methods. Journal of the Air \& Waste Management Association, 57 (2), 146, 2007.

21. USEPA (US Environmental Protection Agency). EPA Positive Matrix Factorization (PMF) 5.0 Fundamentals \& User Guide, 2014.

22. FU J., SHENG S., WEN T., ZHANG Z.M., WANG Q., HU Q.X., LI Q.S., AN S.Q., ZHU H.L. Polycyclic aromatic hydrocarbons in surface sediments of the Jialu River. Ecotoxicology, 20 (5), 940, 2011.

23. NISBET I.C.T., LAGOY P.K. Toxic equivalency factors (TEFs) for polycyclic aromatic hydrocarbons (PAHs). Regulatory Toxicology \& Pharmacology Rtp, 16 (3), 290, 1992.

24. MALISZEWSKA-KORDYBACH B. Polycyclic aromatic hydrocarbons in agricultural soils in Poland: preliminary proposals for criteria to evaluate the level of soil contamination. Applied Geochemistry, 11 (1-2), 121, 1996.

25. WANG R.W., ZHANG J.M., LIU J.J., LIU G.J. Levels and patterns of polycyclic aromatic hydrocarbons in coal-fired power plant bottom ash and fly ash from Huainan, China. Archives of Environmental Contamination \& Toxicology, 65 (2), 193, 2013.

26. CUI Y., GUO L.L., ZHANG G.X., HONG-YAN L.I., QIU-SHENG H.E. Human health risks of PAHs in soils and agricultural products in coking areas, Shanxi Province, China. Journal of Agro-Environment Science, 34 (1), 72, 2015 [in Chinese with English abstract].

27. BIACHE C., MANSUY-HUAULT L., FAURE P., MUNIER-LAMY C., LEYVAL C. Effects of thermal desorption on the composition of two coking plant soils: impact on solvent extractable organic compounds and metal bioavailability. Environmental Pollution, 156 (3), 671, 2008.

28. WANG R.W., LIU G.J., CHOU C.L., LIU J.J., ZHANG J.M. Environmental assessment of PAHs in soils around the Anhui coal district, China. Archives of Environmental Contamination \& Toxicology, 59 (1), 62, 2010.

29. DUAN Y.H., SHEN G.F., TAO S., HONG J.P., CHEN Y.C., XUE M., LI T.C., SU S., SHEN H.Z., FU X.F., MENG Q.C., ZHANG J., ZHANG B., HAN X.Y., SONG $\mathrm{K}$. Characteristics of polycyclic aromatic hydrocarbons in agricultural soils at a typical coke production base in Shanxi, China. Chemosphere, 127C, 64, 2015.

30. WANG Y., TIAN Z.J., ZHU H.L., CHENG Z.N., KANG M.L., LUO C.L., LI J., ZHANG G. Polycyclic aromatic hydrocarbons (PAHs) in soils and vegetation near an e-waste recycling site in South China: concentration, distribution, source, and risk assessment. Science of the Total Environment, 439 (22), 187, 2012.

31. TANG X.J., SHEN C.F., CHEEMA S.A., CHEN L., XIAO X., ZHANG C.K., LIU W.L., LI F., CHEN Y.X. Levels and distributions of polycyclic aromatic hydrocarbons in agricultural soils in an emerging e-waste recycling town in Taizhou area, China. Journal of Environmental Science \& Health Part A Toxic/hazardous Substances \& Environmental Engineering, 45 (9), 1076, 2010.

32. SHEN C.F., CHEN Y.X., HUANG S.B., WANG Z.J., YU C.N., QIAO M., XU Y.P., SETTY K., ZHANG J.Y., ZHU Y.F., LIN Q. Dioxin-like compounds in agricultural soils near e-waste recycling sites from Taizhou area, China: chemical and bioanalytical characterization. Environment International, 35 (1), 50, 2009. 
33. LIU J., LI X.D., CHEN T., QI Z.F., BUEKENS A., LU S.Y., YAN J.H. Polychlorinated biphenyls, polychlorinated dibenzo-p-dioxins and dibenzofurans, and polycyclic aromatic hydrocarbons around a thermal desorption plant in China. Environmental Science and Pollution Research, 22 (5), 3926, 2015.

34. SHEN C.F., TANG X.J., YAO J., SHI D.Z., FANG J., KHAN M.I., ALAM S., CHEN Y.X. Levels and patterns of polycyclic aromatic hydrocarbons and polychlorinated biphenyls in municipal waste incinerator bottom ash in Zhejiang province, China. Journal of Hazardous Materials, 179 (1-3), 197, 2010.

35. SAPONARO S., BONOMO L., PETRUZZELLI G., ROMELE L., BARBAFIERI M. Polycyclic aromatic hydrocarbons (PAHs) slurry phase bioremediation of a manufacturing gas plant (MGP) site aged soil. Water, Air, \& Soil Pollution, 135 (1), 219, 2002.

36. EMOYAN O.O., AGBAIRE P.O., OTOBRISE' C., AKPORHONOR E.E. Distribution pattern of polyaromatic hydrocarbons (PAHs) in soils in the vicinity of fuel stations in Abraka, Nigeria. Journal of Applied Sciences \& Environmental Management, 3, 513, 2011.

37. MARUSENKO Y., HERCKES P., HALL S.J. Distribution of polycyclic aromatic hydrocarbons in soils of an arid urban ecosystem. Water, Air, \& Soil Pollution, 219 (1), 473, 2011.

38. WANG J., ZHANG X.F., LING W.T., LIU R., LIU J., KANG F.X., GAO Y.Z. Contamination and health risk assessment of PAHs in soils and crops in industrial areas of the Yangtze River Delta region, China. Chemosphere, 168, 976-987, 2017.

39. MELNYK A., DETTLAFF A., KUKLIŃSKA K., NAMIEŚNIK J., WOLSKA L. Concentration and sources of polycyclic aromatic hydrocarbons (PAHs) and polychlorinated biphenyls (PCBs) in surface soil near a municipal solid waste (MSW) landfill. Science of The Total Environment, 530-531C (s 1-2), 18, 2015.

40. LI G.Y., SUN H.W., ZHANG Z.Y., AN T.C., HU J.F. Distribution profile, health risk and elimination of model atmospheric SVOCs associated with a typical municipal garbage compressing station in Guangzhou, South China. Atmospheric Environment, 76 (76), 173, 2013.

41. ZHENG T.H., RAN Y., CHEN L.G. Polycyclic aromatic hydrocarbons (PAHs) in rural soils of Dongjiang River basin: occurrence, source apportionment, and potential human health risk. Journal of Soils and Sediments, 14 (1), 110, 2014.

42. KIPOPOULOU A.M., MANOLI E., SAMARA C. Bioconcentration of polycyclic aromatic hydrocarbons in vegetables grown in an industrial area. Environmental Pollution, 106 (3), 369, 1999.

43. LIAO X.Y., MA D., YAN X.L., YANG L.S. Distribution pattern of polycyclic aromatic hydrocarbons in particlesize fractions of coking plant soils from different depth. Environmental Geochemistry and Health, 35 (3), 271, 2013.

44. KATSOYIANNIS A., BREIVIK K. Model-based evaluation of the use of polycyclic aromatic hydrocarbons molecular diagnostic ratios as a source identification tool. Environmental Pollution, 184 (1), 488, 2014.

45. PIES C., HOFFMANN B., PETROWSKY J., YANG Y., TERNES T.A, Hofmann T. Characterization and source identification of polycyclic aromatic hydrocarbons (PAHs) in river bank soils. Chemosphere, 72 (10), 1594, 2008.

46. YUNKER M.B., MACDONALD R.W., VINGARZAN R., MITCHELL R.H., GOYETTE D., SYLVESTRE S. PAHs in the Fraser River basin: a critical appraisal of PAH ratios as indicators of PAH source and composition. Organic Geochemistry, 33 (4), 489, 2002.

47. CHEN W.X. The importance of coal quality testing technology in coal-fired power plants. Heilongjiang Science and Technolog Information, 21, 10, 2011 [In Chinese].

48. WANG W.T., SIMONICH S.L.M., XUE M., ZHAO J.Y., ZHANG N., WANG R., CAO J., TAO S. Concentrations, sources and spatial distribution of polycyclic aromatic hydrocarbons in soils from Beijing, Tianjin and surrounding areas, North China. Environmental Pollution, 158 (5), 1245, 2010.

49. WANG Z., CHEN J., YANG P., QIAO X., TIAN F. Polycyclic aromatic hydrocarbons in Dalian soils: distribution and toxicity assessment. Journal of Environmental Monitoring, 9 (2), 199, 2007.

50. YANG X.X., REN D., SUN W.W., LI X.M., HUANG B., CHEN R., LIN C., PAN X.J. Polycyclic aromatic hydrocarbons associated with total suspended particles and surface soils in Kunming, China: distribution, possible sources, and cancer risks. Environmental Science and Pollution Research, 22 (9), 1, 2015.

51. SIMCIK M., LIOY P.S. Source apportionment and source/ sink relationships of PAHs in the coastal atmosphere of Chicago and Lake Michigan. Atmospheric Environment, 33 (30), 5071, 1999.

52. HARRISON R.M., SMITH D.J.T., LUHANA L. Source apportionment of atmospheric polycyclic aromatic hydrocarbons collected from an urban location in Birmingham, U.K. Environmental Science Technology, 30 (3), 825, 1996.

53. LEE B.K., DONG T.T. Effects of road characteristics on distribution and toxicity of polycyclic aromatic hydrocarbons in urban road dust of Ulsan, Korea. Journal of Hazardous Materials, 175 (1-3), 540, 2010.

54. WANG X.T., MIAO Y., ZHANG Y., LI Y.C., WU M.H., YU G. Polycyclic aromatic hydrocarbons (PAHs) in urban soils of the megacity Shanghai: occurrence, source apportionment and potential human health risk. Science of the Total Environment, 447 (1), 80, 2013.

55. LI A., JANG J.K., SCHEFF P.A. Application of EPA CMB8.2 model for source apportionment of sediment PAHs in Lake Calumet, Chicago. Environmental Science \& Technology, 37 (13), 2958, 2003.

56. MASCLET P., BRESSON M.A., MOUVIER G. Polycyclic aromatic hydrocarbons emitted by power stations, and influence of combustion conditions. Fuel, 66 (4), 556, 1987.

57. VENKATARAMAN C., LYONS J.M., FRIEDLANDER S.K. Size distributions of polycyclic aromatic hydrocarbons and elemental carbon. 1. sampling, measurement methods, and source characterization. Environmental science \& technology, 28 (4), 555, 1994.

58. YE B.X., ZHANG Z.H., MAO T. Pollution sources identification of polycyclic aromatic hydrocarbons of soils in Tianjin area, China. Chemosphere, 64 (4), 525, 2006.

59. ZHANG Z.H., TAO S., YE B.X., PENG Z.Q., YUAN J.P. The main source and identification marks of hydrocarbon pollutants in soils and sediment. Chinese Journal of Soil Science, 35 (6), 793, 2004 [In Chinese).

60. VENKATESAN M.I. Occurrence and possible sources of perylene in marine sediments-a review. Marine Chemistry, 25 (1), 1, 1988.

61. ROGGE W.F., HILDEMANN L.M., MAZUREK M.A., CASS G.R., SIMONEIT B.R.T. Sources of fine organic aerosol. 2. noncatalyst and catalyst-equipped automobiles 
and heavy-duty diesel trucks. Environmental Science and Technology; (United States), 27 (4), 636, 1993.

62. AHLBERG M., BERGHEM L., NORDBERG G., PERSSON S.A., RUDLING L., STEEN B. Chemical and biological characterization of emissions from coal- and oilfired power plants. Environmental Health Perspectives, 47, $85,1983$.

63. ZHANG H., LU J.F., XU X.Q., ZENG R.L., YUE G.X Analysis and possible solutions for the combustion problems of boilers with arc-firing. Chinese Journal of Power Engineering, 25 (5), 628, 2005 [In Chinese with English abstract].

64. YUAN J.P., WANG X.L., ZHOU J.B., CHEN X.F., ZHAO R.S., CHENG C.G. Distribution, source and risk analysis of polycyclic aromatic hydrocarbons in top-soil from Jinan City. Environmental Chemistry, 34 (1), 166, 2015 [In Chinese with English abstract]
65. JIANG Y.F., WANG X.T., WANG F., JIA Y., WU M.H., SHENG G.Y., FU J.M. Levels, composition profiles and sources of polycyclic aromatic hydrocarbons in urban soil of Shanghai, China. Chemosphere, 75 (75), 1112, 2009.

66. FENG A.H., ZHU Z.C., CHEN S.J., WANG J., LUO X.J., MAI B.X. Spatial distribution and risk assessment of polycyclic aromatic hydrocarbons in soils of Shouguang City, North China. China Environmental Science, 33 (9), 1607, 2013 [In Chinese with English abstract].

67. HOU Y.W., ZHANG Y.C. Pollution characteristics and risk assessment of PAHs in surface soils in steel works of Fujian. Environmental Chemistry, 31 (10), 1542, 2012 [In Chinese].

68. CCME (Canadian Council of Ministers of the Environment). Polycyclic aromatic hydrocarbons. Canadian soil quality guidelines for protection of environmental and human health. Canada Soil Quality Guidelines, 2010. 